\title{
Reducing Laboratory Test Waste in the Coating Development Process
}

\author{
Benjamin Urh*, Marjan Senegačnik, Tomaž Kern, Eva Krhač \\ Laboratory of Enterprise Engineering, Faculty of Organizational Sciences, University of Maribor, Slovenia
}

Received: 12 November 2019

Accepted: 29 January 2020

\begin{abstract}
The article proves the possibility of reducing the negative environmental impacts that arise in the new coating development by redesigning the process and implementing modern informational technologies. Environmental standards in the coating industry are becoming strained, but at the same time the market requires products that provide better protection. In new product development, the key factor is efficiency as it is important to develop a new product in the shortest possible time with the lowest costs. The development process is carried out with a laboratory testing a large number of formulations relatively early while only a few of them meet technical requirements. They are also often not economically viable or acceptable from an environmental point of view. Using the innovative information solution, process workflow was improved. By obtaining data from cloud databases, the environmental relevance as well as the price acceptability of each formulation can be checked, even before the laboratory tests were carried out. Consequently, only those formulations that were environmentally and cost suitable were tested. In this way, the number of laboratory tests were significantly minimized, and consequently amounts of waste were reduced to a minimum.
\end{abstract}

Keywords: sustainable formulation, hazardous waste, coatings development, business process redesign, digitalization

\section{Introduction}

Manufacturers in the coating industry are faced with challenges of increasing magnitude. On the one hand, customers are demanding coatings that ensure ever more effective protection of the substrate but, at the same time, meet the relevant aesthetic criteria (brilliance, colour, etc.). On the other hand, environmental protection requirements are being tightened constantly.

*e-mail: benjamin.urh@um.si

Therefore, the use of some substances that increase the effectiveness of coatings are being discontinued or heavily restricted $[1,2]$. The third important aspect is, of course, economic: a manufacturer has to have the price of a product in mind all the time. Optimising these factors when developing a product is an extremely demanding task; moreover, manufacturers are faced with heavy competition. For example, in the EU-28 in 2016 there were 3,865 companies involved in the manufacture of paints, lacquers and related coatings, printer inks and body fillers [3].

Coatings, like some other products (e.g., cleaning agents and personal care products), require relatively complicated formulations consisting of ingredients' 
various classes. Preparing formulation should involve environmental friendliness and health safety as well as affordability of ingredients. So-called environmentally friendly (often designed as "green" or "sustainable") ingredients should have a lower degree of environmental or health risk than known alternatives [4]. The coating industry also has to follow trends in modern production where it is of increasing importance to optimize the degree of materials and energy utilization and to minimize the environmental impact [5-7]. Because the waste generated in the coating industry includes a considerable share of hazardous waste and the principle of waste minimization is particularly important [8]. Sustainable production now has many possibilities because of the development of informational technology with cloud databases [9].

Advances in nanotechnology have had a very great impact on the coatings development in recent years, as the use of nanoparticles enables specific coatings to be given certain specific attributes that the use of micrometric particles cannot give them. From the environmental aspect, one of the main requirements is for the use of hexavalent chromium compounds to be abandoned because of their toxicity and carcinogenicity [10-13]. Coatings containing hexavalent chromium provide excellent anti-corrosion protection. Consequently, it is difficult to replace hexavalent chromium compounds with other substances. This presents manufacturers with a considerable challenge. The use of hexavalent chromium has already been heavily restricted in recent years throughout the world, although there are still allowances made for highly sensitive aircraft parts. European regulations restrict the use of hexavalent chromium compounds in conversion coatings to a maximum $0.1 \%$ by weight, and the requirements are getting ever stricter in the US $[13,14]$. Similarly, there are restrictions of cadmium and cyanide use in the production of coatings [15]. Another emphasized problem in the coatings industry is volatile organic compounds' (VOC) emissions [1619]. There has been a noticeable trend over the last few years in the use of water-based solvents in place of organic solvents. Therefore, as stated in Phulpoto et al. [20], the worldwide production of industrially applied paints increased from 6,3 million tons in 1980 to 10,5 million tons in 2006 (67\% increase). Meanwhile, the consumption of solvents in the same period rose only from 4,1 million tons to 4,2 million tons $(2,5 \%$ increase). Also, great advances have been made in the development of water-based solvents, although a compromise must be sought between environmental protection and price aspects [13, 21-24].

According to Partidário and Vergragt [25], paint (coating) chain consists of the following phases: 1) Production and supply of raw materials, 2) Paint (coating) production, 3) research and development (R\&D), 4) Coating applications, 5) Use of a product protected by coating and 6) Waste management (end of life product disposal or recycling). The environmental problems and principles of sustainability are taken into consideration when raw materials and coatings are being manufactured and used (application of a coating on a substrate) and when products are being used and disposed of once they reach the end of their useful life. There is particular emphasis on exposure of workers to harmful atmospheres during the production and application of coatings [13, 25]. However, as the entire lifecycle of a product has to be taken into account when examining the environmental aspects, any examination of environmental impact cannot ignore the R\&D phase. As the number of requirements regarding the quality and aesthetic criteria of coatings is increasing all the time, the development process is becoming more and more complex. The development of such products also includes a considerable amount of laboratory work, from the synthesis and mixing of ingredients to the testing of the effectiveness and durability of coatings. With coatings having to ensure effective protection for as long as possible, laboratory testing often takes place under strict conditions that require the use of certain aggressive chemicals. It is therefore clear that laboratory activities also cause significant changes to the environment. In practice, it is often the case that a coating that has successfully passed a long series of laboratory tests does not meet contemporary environmental protection standards on account of its composition. Therefore, it would make sense to check in advance whether the composition proposed for a coating meets environmental protection standards applying to a certain market. This would avoid laboratory procedures that, in addition to taking time and incurring costs [26], also produce considerable amounts of waste [27] that can be classified as hazardous. In any case, modern guidelines on waste have to be followed. These prioritise the prevention of waste formation or the reduction in the amounts of waste produced, according to the concepts of ZERO waste and eco-efficiency [2835].

These questions were also asked when the coatings development process was studied. The research purpose was to investigate whether the process can be rationally improved (according to the above requirements) using cloud-based information technology and a "big data" approach. In order to carry out the research, a research sample of several companies involved in the production of coatings was selected. A group of small and medium-sized enterprises was included in the sample. All these enterprises perform the development process in a conventional manner - without the use of information technology, which would enable digital transformation.

In the future it will be most important to pay considerable attention to the concepts of sustainability in the phase of product development [36-38]. Therefore, the present paper describes an example of process redesign, which will contribute to the higher degree of process sustainability. Section 2 describes the coatings development process and research procedure while 
section 3 presents results and discussion of the research. Section 4 concludes the article.

\section{Methods}

\section{Process of Coatings Development (as a Research Fundamental)}

As has already been mentioned, the development of new products in the coatings sector is becoming increasingly more complex as the products have to meet a raft of requirements. A coating contains a series of ingredients: resins, additives, pigments, fillers, catalysers, solvents, etc. Because the number of possible ingredients that can be included in the formulation is very large, the systems by creating a new coating are quite complex $[39,40]$. As C. Bramlage illustrates in Coatingstech's reference [41], assuming the manufacturer can choose from 10 different resins, 10 pigments, 10 catalysers and 10 additives, this represents 10,000 different combinations from a qualitative viewpoint only. In addition, there exist variations in the ratio of quantities of the individual ingredients. The use of information technology is therefore becoming more or less indispensable in the product-planning process. Cole and Hughes [12] point out that three technologies or approaches have become established in the production of anti-corrosion coatings since 2005: high-flow studies, multiscale modelling and self-healing coatings. Multiscale modelling (MSM) enables a fairly accurate forecast of the properties and useful life of coatings, and therefore makes virtual planning possible. Self-healing is based on the ability of a coating to renew or repair itself. This is the safest method, as errors and damage can never be ruled out. High-flow experimentation enables a large number of tests to be carried out at the same time. Chemically very similar ingredients that differ from each other only minimally in terms of molecular structure can also be tested [12]. Manufacturers are placing considerable emphasis on developing state-of-the-art laboratory equipment that, with the help of automation and robotisation, enables a large number of tests to be performed in a short time. In this way, laboratory equipment systemically checks a large number of ingredients under variable conditions [40].

Because of requirements in coating products, the coatings industry has following the lead of other industrial sectors (such as pharmaceuticals), which have begun to develop high-flow systems that incorporate computer simulation [39, 42-44]. The development of laboratory equipment increases test speeds and thereby enables a higher number of measurements performed in a specific period. While this helps to reduce the amount of time spent on the product development process, technological development is not enough on its own. It is very important to estimate the environmental and health hazards of a product from the ingredients hazard data at the stage of formulation preparation [45]. Modern information technology offers great opportunities for improvement as it enables processes to be streamlined to a considerable extent $[26,46]$.

According to the conventional way of working, manufacturers frequently prepare a large number of potential products and then test them in the laboratory. Products that prove to be suitable from a technological point of view (they provide good protection to the substrate, meet aesthetic criteria, etc.) then become eligible to be incorporated into the regular manufacturing process and placed on the market.

\section{Research Procedure}

We found that significant progress in the coatings' $R \& D$ process can be made by innovative information and communication technologies (ICT) combined with a digitalization approach [47].

A process analysis is necessary for digital transformation of the coatings' development process. This requires acquisition of relevant and up-to-date data, development of adequate process models and selection of a "technological enabler" [48]. Targeted interviews were used for acquisition of process execution data.

Process models in the adequate repository are necessary for business process analysis and redesign. As ARIS methodology presents a user perspective of the process [49-51], it was found to be the most appropriate tool for modeling. The event-driven process chain (EPC) model type was used. The EPC model is based on the logic that an event triggers an activity (or several activities). Therefore, a particular activity ends with a new event or with several events. Business objects and relations were designed by standard symbols [52].

For a complete analysis, it was necessary to obtain data on the number of necessary laboratory test repetitions for a successful realization of coating development. Depending on the purpose of the research, data on the waste amounts generated during laboratory tests were also obtained.

The main purpose of the process redesign is to rationalize the number of tests performed in laboratory. This can be achieved when instant and free access to structured data bases of ingredients is given to the formulator. These data bases should exist in a digital form in a cloud and contain up-to-date and precise data on a large number of ingredients (resins, pigments, catalysts and additives). In such a way, the formulator will be able to prepare in real time a coating formulation that will be acceptable from the viewpoint of functional relevance, health suitability, environmental acceptance and affordability. The advantage of the redesign is that when composition of the formulation is known, all necessary documentation (i.e., hazard labels, safety data sheets, technical data sheets) can be prepared. On the basis of this, all formulations that are not acceptable for health, environmental or economic reasons can be 
excluded and thus it is possible to avoid unnecessary laboratory tests. Considerable reduction of laboratory tests will contribute to waste minimization as well as to reduced use of water and energy. In addition, a development's throughput time can be reduced and its costs can be minimized.

The necessary condition for this process redesign is the availability of a technical enabler. Such a technical enabler already exists and is used as an information tool of the $4^{\text {th }}$ generation [53]. This tool is at the stage of prototype testing. According to the present research, it is the only all-in-one tool that enables online, realtime searching for ingredients of coatings, virtual formulation of coatings and preparation of digital technical and safety data sheets.

The proposed process redesign was implemented in the selected company. Based on the obtained results, its suitability was checked.

\section{Results and Discussion}

\section{Analysis of the Existing Coating Development Process}

Different development processes can be basically classified into two categories: conventional process (new product development without ICT support) and new product development process with ICT support and the use of a local database.

In Table 1 and Fig. 1, results of process activities analysis are shown: data on their execution probability, average number of repetitions and waste formation.

Table 1 shows that waste is generated in product laboratory testing, external validation and internal validation.

Regarding the aim of the research (to analyse the possibility of reducing waste in the new coating development process), data on the amounts of waste generated by individual companies in the execution

Table 1. Key activities of the existing new coatings development process.

\begin{tabular}{|c|c|c|c|c|}
\hline \multicolumn{5}{|c|}{ New coatings development process } \\
\hline \#\# & Process activities & Probability $^{\mathrm{a}}$ & Average number of repetitions ${ }^{\mathrm{b}}$ & Waste formation \\
\hline 10 & Creating a new product idea & 0,06 & $0,14^{\mathrm{c}}$ & \\
\hline 20 & Market analysis of existing products & 1,00 & 2,29 & \\
\hline 30 & Searching for suitable binders & 0,92 & 2,29 & \\
\hline 40 & Study of binders properties & 1,00 & 2,50 & \\
\hline 50 & Searching for pigments & \multirow{4}{*}{0,19} & \multirow{4}{*}{2,50} & \\
\hline 60 & Searching for additives & & & \\
\hline 70 & Searching for solvents & & & \\
\hline 80 & Searching for fillers & & & \\
\hline 90 & Formulation (modified) formulations & 1,00 & 13,33 & \\
\hline 100 & Ordering samples & 1,00 & 13,33 & \\
\hline 110 & Product laboratory testing & 0,50 & 13,33 & Yes \\
\hline 120 & Product parameters measurement & \multirow{3}{*}{0,40} & \multirow{3}{*}{6,67} & \\
\hline 130 & Product hazard identification & & & \\
\hline 140 & Product price calculating & & & \\
\hline 150 & Internal validation & 0,50 & 2,67 & Yes \\
\hline 160 & External validation & 0,75 & 1,33 & Yes \\
\hline 170 & Preparation of documentation draft & 1,00 & 1,00 & \\
\hline 180 & Creating documentation & 1,00 & 1,00 & \\
\hline
\end{tabular}

${ }^{a}$ The probability of executing an individual activity according to the decisions during the process. With the exclusion of activity " 10 ", there exists probability that the activity is included in the process. Probabilities for activities that are running parallel (simultaneously) can be found in merged fields.

${ }^{\mathrm{b}}$ The average number of each activity repetitions for the one product development is given. It is calculated on the basis of data on the number of each activity execution repetitions and the number of developed products in selected companies in 2018 c. Because the process has several potential start-events, the activity "Creating a new product idea" is rarely performed. In approximately seven cases of developed products, only once did the idea for a new product arise in this activity. Other ideas are given by other stakeholders; ingredient/binder supplier or costumer can request for new product or for product modification. 


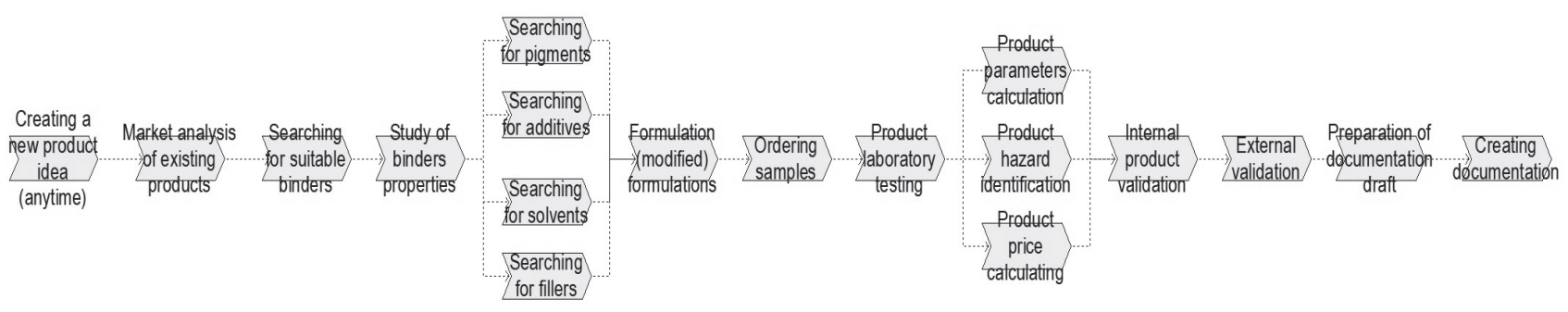

Fig. 1. Model overview of the existing new coatings development process.

of laboratory testing of each coating pattern were obtained.

In the research, the amounts of material used during laboratory tests were not explicitly measured. Therefore, savings can be accurately provided only in percentages as absolute values were estimated only on the basis of assumptions. It is assumed that the average amount of ingredients in one sample is between 0.25 and $2.5 \mathrm{~kg}$. Therefore, for a calculation of waste reduction, $1 \mathrm{~kg}$ of waste may be considered on average to be generated in one test sample. In one execution of laboratory testing, 20-50 samples are prepared and tested. Therefore, for a calculation of waste reduction, 35 samples may be considered as the average number of samples.

The following formulas were used to calculate the generated waste in the development process of one coating:

$$
m_{s}=\sum_{i=1}^{n} m_{i}
$$

$m_{s}$ - mass of waste

$m_{i}$ - mass of individual ingredient's waste

$n$ - number of ingredients in the proposed formulation

$$
m_{t}=\sum_{j=1}^{m} \sum_{i=1}^{n} m_{i}
$$

$m_{t}$ - mass of waste formed in individual laboratory testing for a group of formulations

$m_{i}$ - mass of an individual ingredient's waste

$n$ - number of ingredients in the proposed formulation

$m$ - number of formulations in a particular generation

$$
m_{p}=\sum_{k=1}^{p} \sum_{j=1}^{m} \sum_{i=1}^{n} m_{i}
$$

$m_{p}$ - mass of waste formed at the new product development process

$m_{i}$ - mass of an individual ingredient's waste

$n$ - number of ingredients in the proposed formulation

$m$ - number of formulations in the group

$p$ - number of testing generations

Based on the obtained data and assumptions and formulas noted above, we calculated that the average amount of waste in the new product development process is $467 \mathrm{~kg}$.

\section{Proposal of the Coatings Development Process Redesign}

Not uncommonly, a product that has passed the exacting testing phase and shown itself to be technologically suitable (effective, durable, etc.) is shown not to meet environmental and health standards. The cause is unsuitable composition - which could have been established at the initial stage. The laboratory testing phase could therefore have been avoided for saving time, materials and energy. This gives rise to considerable costs and, as is particularly highlighted in this paper, certain amounts of waste, some of which can be classified as hazardous.

The solution of shortening the development processes is therefore known. In order to implement the solution, the formulator needs data on the large number of potential ingredients at the start of the development process. In principle, this data can be obtained. It can be found on technical information documents, safety documents and ingredient price lists provided by manufacturers. The data is publicly available. It can be obtained most often on the basis of a request together with an ingredient sample. As a rule, the data comes in the form of paper documents or electronic documents in pdf format.

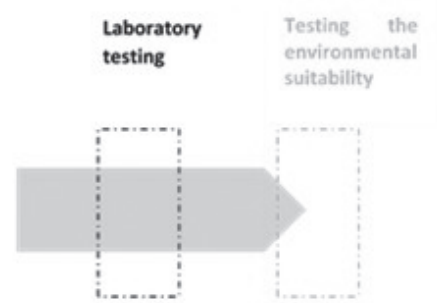

Problem: a large number of laboratory tests, significant amounts of waste (including hazardous waste), high energy and water consumption

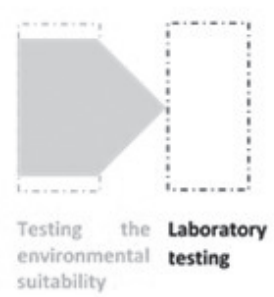

Solution: redesigned process, which allows a significant reduction in the number of laboratory tests, an appropriate reduction in waste amounts, lower carbon and water footprint of laboratory tests

Fig. 2. Schematic comparison between the a) conventional and b) redesigned processes. 


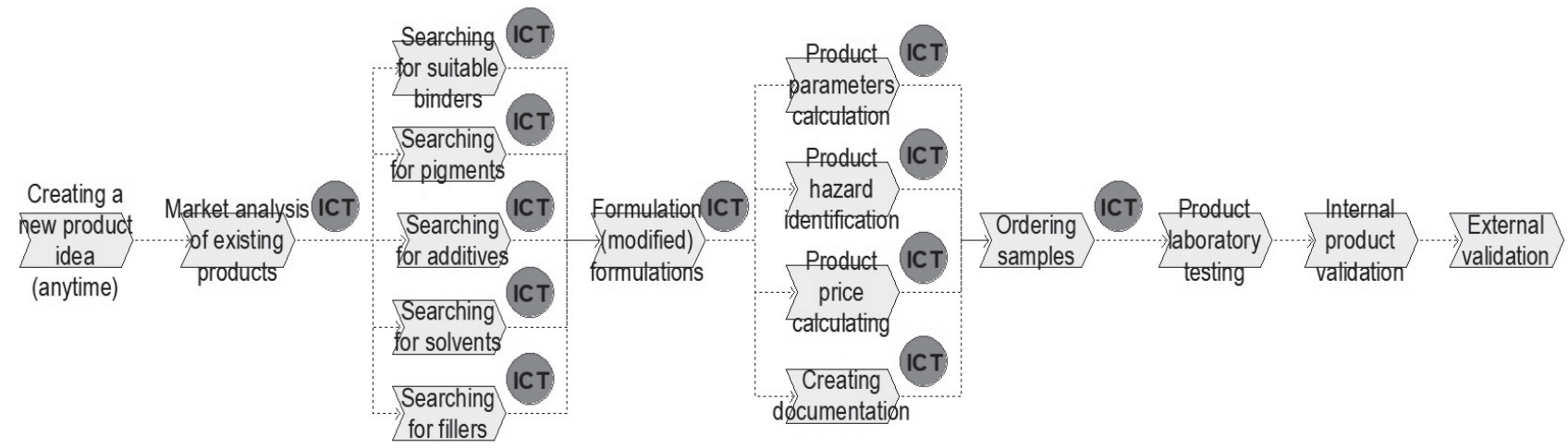

Fig. 3. Model overview of the modified (redesigned) new product development process with ICT support and the use of a cloud-based database.

This is where the problem arises. Obtaining this data is usually a more difficult and more protracted process for the formulator than laboratory testing. If we want to obtain all the data for a large number of potential ingredients, this would take more time than is available for the coating development. Even if a company that develops and manufactures coatings creates its own collection of documents on ingredients (something companies indeed generally do), a further problem arises: the data, particularly price data, on a specific

Table 2. Key activities of the new product development process with ICT support and the use of a cloud-based database.

\begin{tabular}{|c|c|c|c|c|}
\hline \multicolumn{5}{|c|}{$\begin{array}{l}\text { New product development process with ICT support } \\
\text { and the use of a cloud-based database }\end{array}$} \\
\hline \#\# & Process activities & Probability $^{\mathrm{a}}$ & Average number of repetitions ${ }^{b}$ & Waste formation \\
\hline 10 & Creating a new product idea & 0,06 & $0,07^{\mathrm{c}}$ & \\
\hline 20 & Market analysis of existing products & 0,92 & 1,15 & \\
\hline 30 & Searching for suitable binders & \multirow{5}{*}{0,19} & \multirow{5}{*}{1,25} & \\
\hline 40 & Searching for pigments & & & \\
\hline 50 & Searching for additives & & & \\
\hline 60 & Searching for solvents & & & \\
\hline 70 & Searching for fillers & & & \\
\hline 80 & Formulation (modified) formulations & 1,00 & 6,67 & \\
\hline 90 & Product parameters calculation & \multirow{4}{*}{0,80} & \multirow{4}{*}{6,67} & \\
\hline 100 & Product hazard identification & & & \\
\hline 110 & Product price calculating & & & \\
\hline 120 & Creating documentation & & & \\
\hline 130 & Ordering samples & 1,00 & 5,33 & \\
\hline 140 & Product laboratory testing & 0,50 & 5,33 & Yes \\
\hline 150 & Internal validation & 0,50 & 2,67 & Yes \\
\hline 160 & External validation & 0,75 & 1,33 & Yes \\
\hline
\end{tabular}

a The probability of executing an individual activity according to the decisions during the process. With the exclusion of activity "10", there exists probability that the activity is included in the process. Probabilities for activities that are running parallel (simultaneously) can be found in merged fields.

b The average number of each activity repetitions for the one product development is given. It is calculated on the basis of data on the number of each activity execution repetitions and the number of developed products in selected companies in 2018

c. Because the process has several potential start-events, the activity "Creating a new product idea" is rarely performed. In approximately 14 cases of developed products, only once did the idea for a new product arise in this activity. Other ideas are given by other stakeholders; ingredient/binder supplier or costumer can request for new product or for product modification. 
Table 3. Results of the new product development process without ICT support and results with ICT support and the use of a cloud-based database.

\begin{tabular}{|c|c|c|c|c|c|}
\hline \multicolumn{6}{|c|}{$\begin{array}{l}\text { New product development process without ICT support } \\
\text { (the conventional process) }\end{array}$} \\
\hline \#\# & $\begin{array}{c}\text { Process activities } \\
\text { (with waste formation) }\end{array}$ & $\begin{array}{l}\text { Average number of } \\
\text { repetitions }^{\mathrm{a}}\end{array}$ & Number of samples & $\begin{array}{l}\text { Waste / sample } \\
{[\mathrm{kg}]}\end{array}$ & $\begin{array}{l}\text { Waste / activity } \\
{[\mathrm{kg}]}\end{array}$ \\
\hline 110 & Product laboratory testing & 13,33 & 35 & 1 & 466,55 \\
\hline 150 & Internal validation & 2,67 & 1 & 1 & 2,67 \\
\hline 160 & External validation & 1,33 & 1 & 1 & 1,33 \\
\hline \multicolumn{5}{|c|}{ Total waste for one successful product development: } & 470,55 \\
\hline \multicolumn{6}{|c|}{$\begin{array}{l}\text { New product development process with ICT support } \\
\text { and the use of a cloud-based database }\end{array}$} \\
\hline$\# \#$ & $\begin{array}{c}\text { Process activities } \\
\text { (with waste formation) }\end{array}$ & $\begin{array}{c}\text { Average number of } \\
\text { repetitions }\end{array}$ & Number of samples & $\begin{array}{l}\text { Waste / sample } \\
{[\mathrm{kg}]}\end{array}$ & $\begin{array}{l}\text { Waste / activity } \\
{[\mathrm{kg}]}\end{array}$ \\
\hline 140 & Product laboratory testing & 5,33 & 10 & 1 & 53,33 \\
\hline 150 & Internal validation & 2,67 & 1 & 1 & 2,67 \\
\hline 160 & External validation & 1,33 & 1 & 1 & 1,33 \\
\hline \multicolumn{5}{|c|}{ Total waste for one successful product development: } & 57,33 \\
\hline & & & & & $\begin{array}{c}\text { Waste reduction } \\
{[\%]}\end{array}$ \\
\hline & & & & & 87,82 \\
\hline
\end{tabular}

a The average number of each activity repetitions for the one product development is given. It is calculated on the basis of data on the number of each activity execution repetitions and the number of developed products in selected companies in 2018.

ingredient changes over time in response to supply and demand, while the documents in local document collections remain unchanged.

Therefore, the problem cannot be solved through the collection of documentation, even if that documentation is in electronic form. A solution is only possible with the use of original data on ingredients, freely available to the formulator and kept up to date. Therefore, a question arose whether there exists such a solution that would enable the digital transformation of the coatings development process.

After examining and analysing the providers of information solutions for the coatings industry, it has been found that a solution of this type already exists. However, it is not used for the purpose of shortening and simplifying development processes. Instead, it is currently being used as an online service chiefly for the production of technical information documents, safety documents and labels in the final phases of development processes. These documents are accessible in digital form so that their original data can be viewed and used. Of course, documents can be generated at any time and converted into PDF format or printed. The solution is called Allchemist [53] and has been designed to operate in the cloud. A coating's documentation is created using the data on ingredients in the standardised database, which contains technical, safety and other data on all ingredients of all products that the users of the service have formulated up to now. The ingredients database is relatively large and increases in size with every entry made.

The solution can be used as a configurator of formulations as well. The advantage of the configurator of this type lies largely in the fact that it generates safety data alongside chemical composition, while at the same time an individual formulation is being developed. The formulator can identify the chemical properties and environmental acceptability of a formulation as it is being produced. If the ingredients also contain upto-date information on prices, the cost of a coating can therefore be calculated in real time. The particular advantage of a development process designed in this way is that produces a large database of available ingredients that the formulator can choose without wasting time searching and gathering documents on ingredients and copying data into the formulation. This enables the formulator to produce a functionally better coating much more quickly (Fig. 2).

\section{Results of the Redesigned Process}

For the purpose of how the proposed changes impact process execution, an appropriate model of the redesigned process was developed (shown in Fig. 3). The possibilities offered by the inclusion of process support with modern ICT and the use of a cloud-based 


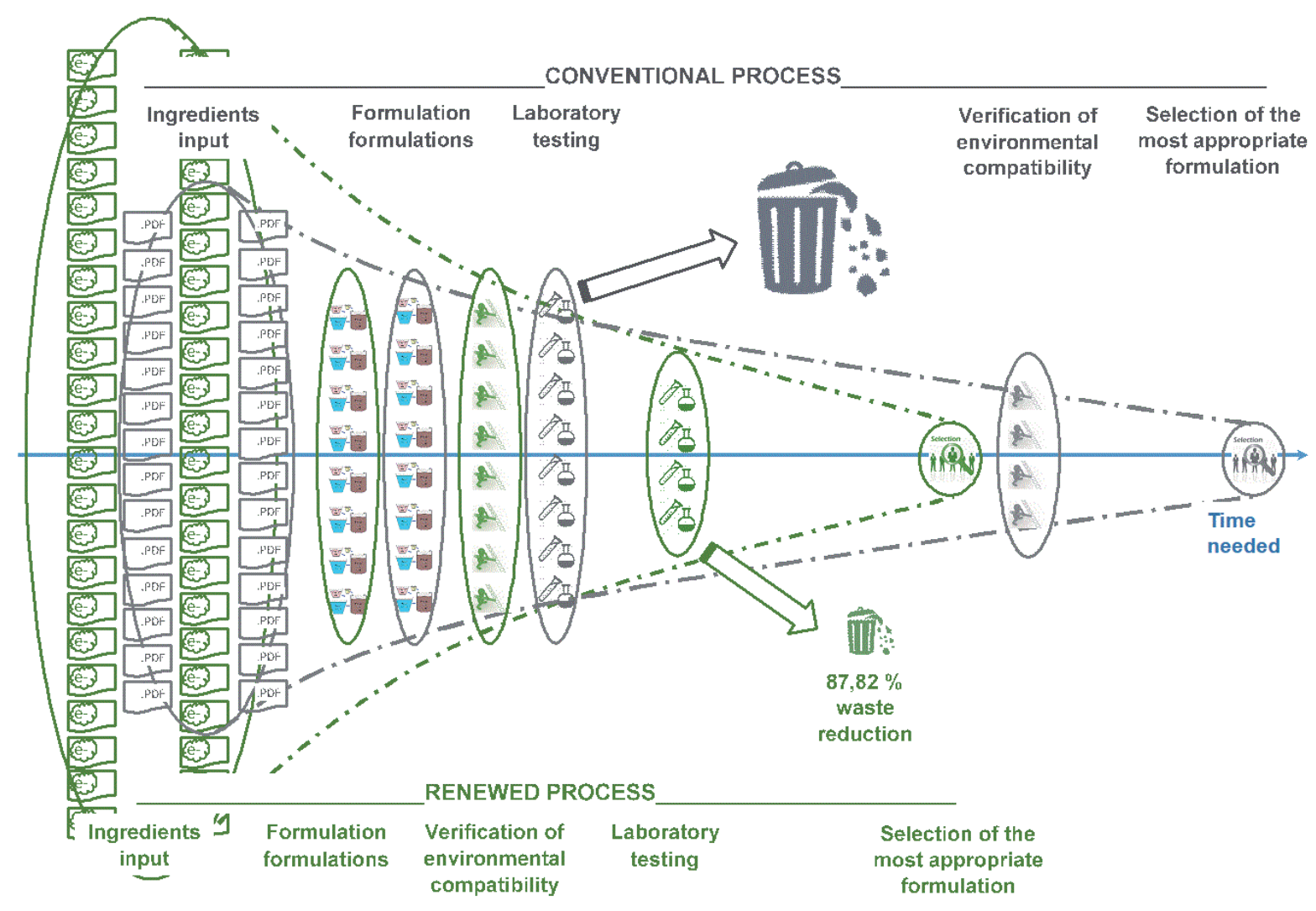

Fig. 4. Schematic presentation of the coatings development process (conventional and redesigned processes).

database have been taken into account, which allows for the inverted sequence of key activities execution in the process (Table 2). This significantly influenced on the number of laboratory tests.

The test of process was performed in a mediumsized company. This company is concerned with development and production of coating using this technical enabler [54]. The tool is used for preparation of safety data sheets in the process of new product development [55]. The company can eliminate in the first stage of the development process those formulations that are not acceptable from environmental or cost viewpoints. However, there exist certain limitations as local databases contains only data on a limited amount of ingredients.

Table 2 presents results for the new product development process with appropriate ICT support and a cloud-based database.

With the same assumption, the average amount of ingredients in one tested sample is $1 \mathrm{~kg}$. In one execution of laboratory testing, due to the changed sequence of activities (preliminary digital testing of formulations), the number of samples at each test is reduced to 5-15. Therefore, for a calculation of waste reduction, 10 samples may be considered the average number. With these findings, we calculated that the average amount of waste in the redesigned development process is $53 \mathrm{~kg}$.

Table 3 presents results of the research, carried out for the new product development process without ICT support and for the redesigned process with appropriate ICT support and a cloud-based database.

In the EU-28 (2016) 3,865 companies are involved in the manufacture of paints, lacquers and related coatings, printer inks and body fillers [3]. It was assumed that each company makes at least three new products every year. Based on this, it has been estimated that reduction of waste can be assessed as between 4,000 and 5,000 tons. A schematic comparison between the conventional and redesigned process is shown in Fig. 4.

\section{Conclusions}

Based on our research, we can conclude that the redesigned process significantly cuts the number of laboratory tests. Therefore, the redesigned process causes considerably less environmental pollution because of the lower amounts of waste produced and the lower quantities of energy and water consumed. This also leads to the more sustainable process of new product development.

It is evident that the problem of development process complexity can be better resolved by reducing the number of re-tests performed in the laboratory than by shortening the periods of time spent on an individual testing procedure. This is possible only if formulations are simulated in advance and individual formulations are checked from the point of view of environmental and price acceptability. This narrows down the 
number of potentially suitable formulations prior to laboratory testing. The environmental acceptability of a formulation depends on the coating's ingredients and on their respective proportions within the coating. Therefore, when a formulator has this information, then he or she can calculate the overall environmental acceptability of the coating. The same is true when it comes to calculating the cost price, which depends on the prices of individual ingredients, their respective proportions and the price attached to the technological procedure of manufacturing the coating. When this information is available, a precise calculation of the coating cost can be made. Other advantages of the redesigned process are a shorter process execution time, a greater set of available information and a technically better solution (optimal coating).

The used information solution is useful, not only for formulators or coatings manufacturers but also for ingredients suppliers, which can add up-to-date information about their products to databases.

In the field of coating development's impact on the environment, a wider research should be carried out to determine the actual amounts of waste, by individual types, that are formed. This will demonstrate the actual level of reducing the environmental load on waste by using the redesigned process. At the same time, it would be worth exploring the reduction of environmental impact due to redesign in terms of water consumption, energy and cleaning products.

\section{Acknowledgements}

The authors are grateful to the Laboratory of Enterprise Engineering, Faculty of Organizational Sciences, University of Maribor for supporting our project.

\section{Conflict of Interest}

The authors declare no conflict of interest.

\section{References}

1. EUR - Lex, Access to European Union law (Directive 2004). Directive 2004/42/CE of the European Parliament and of the Council of 21 April 2004 on the limitation of emissions of volatile organic compounds due to the use of organic solvents in certain paints and varnishes and vehicle refinishing products and amending Directive 1999/13/EC [Internet]. 2004 apr 21. Available online: https://eur-lex. europa.eu/legal-content/EN/TXT/HTML/?uri=CELEX:32 004L0042\&from=SL (accessed on 7. November 2019).

2. EUR - Lex, Access to European Union law (Directive 2010). Directive 2010/75/EU of the European Parliament and of the Council of 24 November 2010 on industrial emissions (integrated pollution prevention and control) [Internet]. 2010 nov 24 [cited 2019 sept 12]. Available online: https://eur-lex.europa.eu/legal-content/EN/ TXT/?uri=CELEX\%3A32010L0075 (accessed on 7. November 2019).

3. Eurostat. Industry by employment size class (NACE Rev 2, B-E) Manufacture of paints, varnishes and similar coatings, printing ink and mastics. 2019 Available online: https:// appsso.eurostat.ec.europa.eu/nui/submitViewTableAction. do (accessed on 7. November 2019).

4. JESSOP P.G., AHMADPOUR F., BUCZYNSKI M.A., BURNS T.J., GREEN II N.B., KORWIN R., LONG D., MASSAD S.K., MANLEY J.B., OMIDBAKHSH N., PEARL R., PEREIRA S., PREDALE R.A., SILVA P.G., VANDERBILDT H., WELLER S., WOLF M.H. Opportunities for greener alternatives in chemical formulations. Green Chemistry 17, 2664, 2015.

5. KLEMEŠ J.J., HUISINGH D. Making progress toward sustainability by using cleaner production technologies, improved design and economically sound operation in production facilities. Journal of Cleaner Production. 13, $451,2005$.

6. HENNEBERT P., VAN DER SLOOT H.A., REBISCHUNG F., WELTENS R., GEERTS L., HJELMAR O. Hazard property classification of waste according to the recent propositions of the EC using different methods. Waste Management. 34 (10), 1739, 2014.

7. SONG M.L., CEN L., ZHENG Z.X., FISHER R., LIANG X., WANG Y.T., HUISINGH D. How would big data support societal development and environmental sustainability? Insights and practices. Journal of Cleaner Production 142, 489, 2017.

8. DURSUN D., SENGUL F. Waste minimization study in a solvent-based paint manufacturing plant. Resources, Conservation and Recycling. 47, 316, 2006.

9. LI X.X., HE F.Z., LI W.D. A cloud-terminal-based cyberphysical system architecture for energy efficient machining process optimization. Journal of Ambient Intelligence and Humanized Computing 10, 1049, 2019.

10. COSTA M., KLEIN C.B. Toxicity and carcinogenicity of chromium compounds in humans. Crit Rev Toxicol. 36,155, 2006.

11. BIERWAGEN G., BROWN R., BATTOCCHI D., HAYES S. Active metal-based corrosion protective coating systems for aircraft requiring no-chromate pretreatment. Progress in Organic Coatings. 67,195, 2009.

12. COLE I.S., HUGHES A.E. Designing molecular protection: new paradigm for developing corrosion resistant materials uniting high throughput studies, multiscale modelling and self-repair. Corrosion Engineering, Science and Technology. 49, 109, 2014.

13. DENNIS R.V., PATIL V., ANDREWS J.L., ALDINGER J.P., GANAPATI D.Y., BANERJEE S. Hybrid nanostructured coatings for corrosion protection of base metals: a sustainability perspective. Mater. Res. Express. 2, 1, 2015.

14. BARAL A., ENGELKEN R.D. Chromium-based regulations and greening in metal finishing industries in the USA. Environmental Science \& Policy. 2,121, 2002.

15. ALKAYA E., DEMIRER G.N. Improving resource efficiency in surface in coating/painting industry: practical experiences from a small-sized enterprise. Clean Techn Environ Policy. 16, 1565, 2014.

16. CANEBA G.T., WANG B. Low VOC latex paints from a precipitation polymerization process. Clean Prod Processes. 3, 55, 2001.

17. CHANG C.T., LEE C.H., WU Y.P., JENG F.T. Assessment of the strategies for reducing volatile organic compound 
emissions in the automotive industry in Taiwan. Resources, Conservation and Recycling. 34, 117, 2002.

18. LI J., UTTARWAR R.G., HUANG Y. CFD-based modeling and design for energy-efficient VOC emission reduction in surface coating system. Clean Techn Environ Policy. 15, 1023, 2013.

19. ZHANG Z., CHEN J., GAO Y., AO Z., LI G., AN T., HU Y., LI Y. A coupled technique to eliminate overall nonpolar and polar volatile organic compounds from paint production industry. Journal of Cleaner production 185, 266, 2018.

20. PHULPOTO A.H., QAZI M.A., MANGI S., AHMED S., HAQ I.-U., PHUL A.R., KANHAR N.A. Bioremediation of oil-based pant from aqueous media by novel indigenous brevibacillus parabrevis strain NAP3 and its toxicity assessment. Pol. J. Environ. Stud. 26 (1), 229, 2017.

21. ELMORE J.D., KINCAID D.S., KOMAR P.C., NIELSEN J.E. Waterborne epoxy protective coatings for metal. Journal of Coatings Technology. 74, 63, 2002

22. LI C., CHEN L. Organic chemistry in water. Chem. Soc. Rev. 35, 68, 2006.

23. MONTAZERI M., ECKELMAN M.J. Life cycle assessment of UV-Curable bio-based wood floaring coatings. Journal of Cleaner Production . 192, 932, 2018.

24. MAN L., FENG Y, HU Y., YUAN T., YANG Z. A renewable and multifunctional eco-friendly coating from novel tung oil-based cationic waterborne polyurethane dispersions, Journal of Cleaner Production, 241, Article 118341, 2019.

25. PARTIDÁRIO P.J., VERDRAGT P.H.J. Shaping sustainable technology development in the coatings chain Defining boundaries, environmental problems and main players. Journal of Cleaner Production. 8, 201, 2000.

26. KERN T., KRHAČ E., SENEGAČNIK M., URH B. Digitalizing the paints and coatings development process. Processes. 7, 1, 2019.

27. SENEGACNIK M., KERN T., URH B., KRHAC, E. Reduced environmental pollution in the process of coating development by the use of information technology. In: Sprajc P., Podbregar I., Maletic D., Radovanovic, M., editors. Ecosystem of organizations in the digital age: conference proceedings; 38th International Conference on Organizational Science Development, Portorož (In Slovenian) [Internet]. Maribor: Univerzitetna založba Univerze v Mariboru. P. 957-968. Available online: http:// press.um.si/index.php/ump/catalog/view/397/393/675-3 (accessed on 7. November 2019).

28. EUR - Lex, Access to European Union law (Directive 2008). Directive 2008/98/EC of the European Parliament and of the Council of 19 November 2008 on waste and repealing certain Directives (Text with EEA relevance) [Internet]. 2008 nov 19 [cited 2019 sept 12]. Available online: https://eur-lex.europa.eu/legal-content/EN/ TXT/?uri=CELEX:32008L0098\%20 (accessed on 7. November 2019).

29. WILTS H. National waste prevention programs: Indicators on progress and barriers. Waste Management \& Research 30, 29, 2012.

30. AIVALIOTI M., COSSU R., GIDARAKOS E. New opportunities in industrial waste management. Waste Management. 34 (10), 1737, 2014.

31. PAPARGYROPOULOU E., LOZANO R., STEINBERGER J.K., WRIGHT N., UJANG Z.B. The food waste hierarchy as a framework for the management of food surplus and food waste. Journal of Cleaner Production. 76, 106, 2014.
32. SONG Q., LI J., ZENG X. Minimizing the increasing solid waste through zero waste strategy. Journal of Cleaner Production. 104, 199, 2015.

33. ZORPAS A.A., LASARIDI K., VOUKKALI I., LOIZIA P., CHRONI C. Promoting sustainable waste prevention strategy activities and planning in relation to the waste framework directive in insular communities. Environmental Processes. 2 (1), 159, 2015.

34. PETROVIĆ N., SAVIĆ G., ANDRIJAŠEVIĆ D., STANOJEVIĆ M., ĆIROVIĆ M., SLOVIĆ D. RADAKOVIĆ J.A. Evaluation eco-efficiency of beverage packaging materials: A data envelopment analysis approach. Fresenius Environmental Bulletin 25, 2958, 2016.

35. WIDOMSKI M.K., GLEŃ P., ŁAGOD G. Sustainable landfilling as final step of municipal waste management system. Problems of Sustainable Development. 12, 147, 2017.

36. World Commission on Environment and Development (WCED) (1987) Our common future (Brundtland report). Oxford University Press, Oxford.

37. UDO V., PAWŁOWSKI A. Human Progress Towards Equitable Sustainable Development - part II: Empirical Exploration. Problems of Sustainable Development 6, 33, 2011.

38. PAWŁOWSKI A. Sustainable development and globalization. Problems of Sustainable Development. 8, 5, 2013.

39. BOHORQUEZ S.J., VAN DEN BERG P., AKKERMAN J., MESTACH D., VAN LOON S., REPP J. High-throughput paint optimization by use of a pigment-dispersing polymer. Surface Coatings International. 98, 85, 2015.

40. LANGILLE M., IZMITLI A., LAN T., AGRAWAL A., LIU C., HENDERSON K., LU Y. Balancing performance of slip/mar additives using a high throughput approach. Coatingstech. 14, 52, 2018.

41. COATINGSTECH. Coatings Xperience: Accelerating coatings development with high throughput technology [Internet]. Washington D.C.: American Coatings Association; 2019. Available online: https://www.paint. org/article/accelerating-coatings-development-highthroughput-technology/ (accessed on 7. November 2019)

42. JUDSON R., RICHARD A., DIX D.J., HOUCK K., MARTIN M., KAVLOCK R., DELLARCO V., HENRY T., HOLDERMAN T., SAYRE P., TAN S., CARPENTER T., SMITH E. The toxicity data landscape for environmental chemicals. Environmental Health Perspectives. 117, 685, 2009.

43. DIONISIO K.L., FRAME A.M., GOLDSMITH M.R., WAMBAUGH J.F., LIDDELL A., CATHEY T., SMITH D., VAIL J., ERNSTOFF A.S., FANTKE P., JOLLIET O., JUDSON R.S. Exploring consumer exposure pathways and patterns of use for chemicals in the environment. Toxicology Reports. 2, 228, 2015.

44. DIONISIO K.L., PHILLIPS K., PRICE P.S., GRULKE C.M., WILLIAMS A., BIRYOL D., HONG T., ISAACS K.K. The Chemical and Products Database, a resource for exposure-relevant data on chemicals in consumer products. Scientific Data. 5, 180125, 2018.

45. ASKHAM C., GADE A.L., HANSSEN O.J. Linking chemical risk information with life cycle assessment in product development. Journal of Cleaner Production. 51, 196, 2013.

46. BOKOLO A.J., MAZLINA A.M., AWANIS R. A proposed model for green practice adoption and implementation in 
information technology based organizations. Problems of Sustainable Development. 13, 95, 2018.

47. GARTNER RESEARCH 2018 oct 15 [cited 2019 sept 12]. Available online: https://www.gartner.com/doc/3891665/ cio-agenda-securing-new-foundation (accessed on 7 . November 2019).

48. DIN/DKE - ROADMAP. German stadardization roadmap - Industrie 4.0 - Version 3 [Internet]. Berlin, Frankfurt: Din e.V. and DKE Deutsche Kommission Elektrotechnik Electronic Informationstechnik in DIN und VDE; 2018. 16 p. Available online:_https://www.din.de/blob/65354/57218 767bd6da1927b181b9f2a0d5b39/roadmap-i4-0-e-data.pdf (accessed on 7. November 2019).

49. COTTRELL W.D. Simplified Program Evaluation and Review Technique (PERT). Journal of Construction Engineering and Management. 125, 16, 1999.

50. SCHEER A.W. ARIS - Business Process Framework. 2nd ed. Springer, Berlin, 1998.
51. PAVLOVIĆ I., KERN T., MIKLAVČIČ D. Comparison of paper-based and electronic data collection process in clinical trials: Costs simulation study. Contemporary Clinical Trials. 30 (4), 300, 2009.

52. SÁNCHEZ GONZÁLEZ L., GARCÍA RUBIO F., RUIZ GONZÁLEZ F., PIATTINI VELTHUIS M. Measurement in business processes: a systematic review. Business Process Management Journal 16, 114, 2010.

53. ALLCHEMIST ${ }^{\circledR}$. Digital Platform for experts working in the paint coatings industry who want to work directly with data instead of datasheets 2018. Available online: https:// www.allchemist.net/ (accessed on 7. November 2019).

54. BANKS J., CARSON J.S., NELSON B.L., NICOL D.M. Discrete-event system simulation 5th ed. Pearson Prentice Hall, New Jersey, 2010.

55. GREASLEY A. The case for the organisational use of simulation. Journal of Manufacturing Technology Management. 15, 560, 2004. 